RETRACTION NOTE

\title{
Retraction Note: Downregulation of the long noncoding RNA MBNL1-AS1 protects sevoflurane-pretreated mice against ischemia-reperfusion injury by targeting KCNMA1
}

Xue-Feng Li, Zong-Qiang Wang, Long-Yun Li, Guo-Qing Zhao and Shao-Nan Yu

(c) The Author(s) 2021

Experimental \& Molecular Medicine (2021) 53:1819; https://doi.org/10.1038/s12276-021-00698-5

Retraction to: Experimental \& Molecular Medicine https://doi.org/ 10.1038/s12276-018-0133-y, published online 05 September 2018

The authors have retracted this article. After publication they repeated the experiments further increasing the expression of KCNMA1 but found that this did not activate the CGMP PKG signaling pathway. The authors now believe that the mechanism by which the KCNMA1 gene inhibits the CGMP PKG signaling pathway affecting the disease is not one-to-one regulation. All authors agree to this retraction.

\begin{abstract}
(i) Open Access This article is licensed under a Creative Commons Attribution 4.0 International License, which permits use, sharing, adaptation, distribution and reproduction in any medium or format, as long as you give appropriate credit to the original author(s) and the source, provide a link to the Creative Commons license, and indicate if changes were made. The images or other third party material in this article are included in the article's Creative Commons license, unless indicated otherwise in a credit line to the material. If material is not included in the article's Creative Commons license and your intended use is not permitted by statutory regulation or exceeds the permitted use, you will need to obtain permission directly from the copyright holder. To view a copy of this license, visit http://creativecommons. org/licenses/by/4.0/.
\end{abstract}

(c) The Author(s) 2021 